\title{
CONTEXT AND REINVESTMENT DECISIONS: WHY THE TRANSITIONAL PERIPHERY DIFFERS FROM OTHER POST-STATE SOCIALIST ECONOMIES
}

by

Mehmet Demirbag ${ }^{\mathrm{a}}$ Martina McGuinnness ${ }^{\mathrm{b} \#}$, Geoffrey Wood ${ }^{\mathrm{c}}$ and Nizamettin Bayyurt ${ }^{\mathrm{d}}$

${ }^{a}$ Professor of International Business and Head, Department of Strategy and Organisation, Strathclyde Business School, University of Strathclyde, 199 Cathedral Street, Glasgow, G4 0QU, United Kingdom.

E-mail: mehmet.demirbag@ @strath.ac.uk

${ }^{\mathrm{b}}$ Senior Lecturer, University of Sheffield, Management School, 9 Mappin Street, Sheffield, S1 4DT United Kingdom. E-mail m.mcguinness@sheffield.ac.uk

${ }^{c}$ Professor of International Business, Warwick Business School, The University of Warwick, Coventry, CV4 7AL, United Kingdom. E-mail: Geoffrey.wood@wbs.ac.uk

${ }^{\mathrm{d}}$ Professor of Management, Department of Management, Fatih University, Alkent 2000 Mh., 34500 İstanbul, Turkey. E-mail: bayyurt@fatih.edu.tr

\#Corresponding author:

Dr. Martina McGuinness,

Senior Lecturer in Risk Management and Strategy,

Management School,

University of Sheffield,

Crookesmoor Building,

Sheffield S10 1FL

E-mail: m.mcguinness@ @ sheffield.ac.uk 


\title{
THE LAW, CORRUPTION AND REINVESTMENT DECISIONS: THE
}

\section{TRANSITIONAL PERIPHERY IN COMPARATIVE CONTEXT}

\begin{abstract}
A range of studies has found that corruption has a significant impact upon FDI decisions, however to date there has been scant investigation into longer term investments made by firms and their relative proclivity to reinvest. Further, there is particularly little work on reinvestment choices made on the transitional periphery of post-state socialist countries and how these might differ from the more stable transitional economies of central and Eastern Europe. Utilising 2005 World Bank Enterprise Survey data, this study explores the relationship between corruption and MNEs' strategic decision to reinvest profits. From an institutionalist starting point, we find variation in the impact of different dimensions of corruption upon reinvestment; pervasive corruption impacts negatively upon reinvestment, but its positive effects are less pronounced in the transitional periphery. Perceived robust legal institutions have a positive correlation with reinvestment, but again, the negative effects are most pronounced on the transitional peripheral state socialist states. We ascribe this disparity to greater institutional fluidity, and explore why this context has particularly adverse effects. Finally, we find that firm level attributes of larger size and greater age play an important role in positive reinvestment decisions, appearing to mitigate the worst consequences of this fluidity.
\end{abstract}

\section{KEYWORDS}

Reinvestment, profits, MNE, corruption, transitional periphery. 


\section{THE LAW, CORRUPTION AND REINVESTMENT DECISIONS: THE TRANSITIONAL PERIPHERY IN COMPARATIVE CONTEXT}

\section{INTRODUCTION}

This study explores the relationship between the institutional environment and firm growth, and more particularly, the impact of corruption upon reinvestment decisions by multinational enterprises (MNEs) on the transitional periphery. More specifically, we explore whether reinvestment is lower on the transitional periphery than in other post-state socialist countries and the reasons for this. The former is defined, for the purposes of this article, as those poststate socialist countries characterized by particularly weak or fluid institutions, and where either EU accession is not on the agenda, or it is a remote, or difficult, prospect. This encompasses the peripheral states of the Balkans, and the Post-Soviet republics of the Caucasus, and Central Asia. On the one hand, being a former Soviet republic is clearly not a barrier to Europeanisation, as borne out by the Baltic States. On the other hand, there is little doubt that the historical experience of former Yugoslavia is very different from that of the former Soviet Union. Although such transitional peripheral countries are clearly very different from those more developed post-state socialist countries that have already entered the EU, it could be argued that the peripheral Balkan States (Bosnia-Herzegovina, Albania and Kosova) all share similarities with the republics of Central Asia on the Caucasus in terms of both past legacies and concomitant possible future trajectories. Hence, we further compare these two categories with each other in looking at reinvestment trends.

To date, very little work has been carried out exploring longer term reinvestment decisions and the impact corruption might have upon these in the transitional perpihery. It can be argued that, on account of ambitious experiments in institutional building and redesign following the collapse of the Soviet Union and state socialism more generally, these settings are more fluid institutional environments than many African nations which, although 
characterised by weak institutions, also show long historical continuities (Collins, Uhlenbruck, \& Rodriguez, 2009; Herbst, 2000). This study explores whether the transitional peripheral countries have distinct characteristics in terms of reinvestment choices, and whether the negative consequences of corruption and weak rule of the law are more pronounced in contexts where institutional arrangements are more fluid. Existing research to date on the relationship between investment and environmental uncertainty, especially with respect to the key dimension of corruption, is varied but often disparate (Demirbag, McGuinness \& Altay, 2010). However, in this discussion of the relationship between reinvestment and different types of corruption is remarkably absent. What effect might corruption have upon the reinvestment decision? This is a significant research gap which warrants addressing and consequently, this paper seeks both to make a contribution to a nascent literature and, to point a way forward for future investigation.

\section{LITERATURE REVIEW AND HYPOTHESES DEVELOPMENT}

\section{Institutions and the Transitional Periphery}

The literature on institutions is extensive, but there is broad agreement that institutions are central in determining how secure is an organisation's prosperity (North, 1981:17). Weak institutions can lead to a decrease in corporate transparency and asymmetry of information which can impede capital allocation and investment efficiency (Durnev, Errunza, \& Molchanov, 2010). The late 1990s and early 2000s literature on institutions and firm outcomes has tended to focus on mature economies and/or assume institutional arrangements have been established over a considerable period of time (Dore, 2000; Hall \& Soskice, 2001; La Porta, Lopez, Shleifer, \& Vishny, 1999, 2002). Rational-hierarchical approaches to institutions see their most important consequences in terms of protecting private property 
rights by providing incentives, or disincentives. (La Porta, Lopez, \& Shleifer, 2008; G. T. Wood, 2011; La Porta, Lopez, \& Shleifer, 2008; Wood, 2011). Within the rational hierarchical camp, the work of La Porta and colleagues has been most influential; they see property rights as flowing from a single institutional feature, the law, and the origin of legal arrangements. This approach is not without its problems, in that it discounts the beneficial impact of social ties and social compromises (Hall \& Soskice, 2001). At the same time, it has been highly influential, informing the World Bank Doing Business Guides, which, in turn, is likely to have impacted investor decisions (D. Wood, 2011). Hence, a key focus of the study is the consequences of legal institutions.

However, as Wood and Lane (2012) note, institutional arrangements are not only subject to change, but also vary in their relative fluidity in time and place,. Whilst all institutional arrangements only exist through being constantly reconstituted - and adjusted - through the choices of social actors, this process varies in its intensity according to context (Giddens 1984). Institutional fluidity is defined as a particularly intensive variation of institutional arrangement. In other words, whilst specific rules, conventions and embedded patterns of behaviour may exist, in times of institutional fluidity they are more likely to be contested and radically redefined. It is also easier for players to fully, or partially, disengage from the system where institutions are weak or fluid (Lane \& Wood, 2012). As historical institutionalists note, any social compromises are specific to a particular time period, with compromises inevitably arising in response to severe societal crisis or trauma. Although they may become embedded, simply through a lack of known alternatives or because alternative arrangements do not seem feasible, they will ultimately be open to contestation and redefinition (see Thelen 2010). As a result, whilst societies may experience long-term historical continuities, such continuities are neither indefinite nor immutable. 
This begs the question, how do the countries under review differ from other emerging markets, such as those, for example, in Africa and Asia? Many other emerging markets had institutional arrangements established during the colonial era resulting in long-term legacies (see Acemoglu, Johnson, \& Robinson, 2012; Herbst, 2000). What sets the transitional periphery apart is not simply institutional weakness, but also, it can be argued, greater fluidity. Unlike the case of colonial Africa, the departing Soviet rulers (in the case of the PostSoviet republics) devoted little attention to the institutional legacies left on their departure, resulting in widely divergent institution building experiments. Indeed, it has been argued that the abiding institutional legacies in such countries - the nature of corporate law - predates the Soviet era, and to some extent these have displaced Soviet legal institutions (La Porta, et al., 2008). In the Balkans, there was also variety in the nature of the transitions from, the external protectorate model initially deployed in Bosnia-Herzgovina and Kosovo to, the disorganised and chaotic transition of Albania. What difference does institutional fluidity make? While, for example, it could be argued that Francophone West Africa is characterised by weak property rights (Herbst, 2000; La Porta, et al., 1999), at least investors can have a degree of confidence in basic legal continuities, even at times of constitutional irregularity or military rule. In contrast, across the transitional periphery, rule books have been rewritten, and, within many contexts, are likely to be rewritten again, at least in the medium term (Collins, 2009). In the case of the Central Asian republics, this involved not just economic and political liberalization, but also nation building, rather than the regaining of national independence. Collins (2009) argues that clan politics is a key characteristic of Central Asian states which emerged in the late Soviet era. This made liberalisation not only difficult, but extremely so. Gullette (2010) argues that the extreme nature of the economic transformation resulted in people falling back on personal networks and relations in order to manage the impacts of fluid institutional environments. Consequently, extended family based ties have interpenetrated the polity, making for ongoing struggles over state resources. Auty (2006) suggests that in both 
the Caucasus and Central Asia, economic challenges and political institution construction have gone hand-in-hand with elite continuity, with institutions being remolded to suit elite interests. In a similar vein Thornberry et al (2014) discuss how important a role the informal networks of bazaaries (local merchants) and ulama (religious scholars) played in influencing the Iranian political institutional environment. Finally, it could be argued that the transitional peripheral Balkan economies of Albania and Bosnia-Herzegovina have, again, faced the dual problems of chronic elite failure and resilience, with nation building become disarticulated from the confrontation of structural political problems (see Chandler, 2006). In the context of institutional fluidity, firms may be more likely to feel compelled to seek ad hoc arrangements with political elites. As a consequence, they may be daunted by the greater risks of high corruption or, see it as a normal part of doing business in countries where there are rich natural resource endowments or strategic market possibilities.

\section{Reinvestment Choices}

Reinvestment is key to the firm's success, indeed to its very survival. Reinvestment has been described variously as the decision to expand existing business (McCarthy et al., 1993) and the percentage of profit invested into company (Cull \& Xu, 2005). Variables which have been identified as relevant to enhancing organisational longevity include factors for which reinvestment can be key, such as the scale of operation (Bercovitz \& Mitchell, 2007; Li, 1995), growth strategies (Mata \& Portugal, 2002) and resource utilisation (Bercovitz \& Mitchell, 2007; Bradley, Aldrich, Shepherd, \& Wiklund, 2011). Size is well established in the literature as a critical factor in firm survival (Aldrich \& Auster, 1986; Bercovitz \& Mitchell, 2007; Geroski, Mata, \& Portugal, 2010; Demirbag, Tatoglu and Apaydin, 2012; Mitchell, 1994; Sarkar, Echambadi, Agarwal, \& Sen, 2006). 
Writing from an international business standpoint, Wren \& Jones (2009) found that foreignowned plants had higher exit rates but that reinvestment increased the life-time of start-up plants while Mudambi (1998) found that MNEs with longer tenure were more likely to reinvest. It is worth noting that, whilst neither authors adopted an institutional perspective, both studies were conducted in England, a developed economy with strong institutions. Institutional factors have been acknowledged as significant for reinvestment decisions (Cull \& Xu, 2005; Johnson, McMillan, \& Woodruff, 2002) as well as repatriation of earnings (Lundan, 2006). Although Cull \& Xu (2005) found that contract enforcement did impact upon reinvestment, they did not explore this within additional dimensions of corruption. However, there are some indications that the importance of secure property rights may vary according to firm size. One cross-country analysis of small business reinvestment in emerging economies showed that access to external finance proved more significant in small firms' reinvestment decisions than the security of property rights (Chakravarty \& Xiang, 2011; Piwakowski and Trojanski 2014). In terms of survival and exit (divestment) strategies, the picture is equally varied (Chung \& Beamish, 2005; Doh, Rodriguez, Uhlenbruck, Collins, \& Eden, 2003; Hallward-Driemeier, 2009; Lu \& Xu, 2006; Mata \& Portugal, 2002). So, for example, Hallward-Driemier (2009) argued that in countries with higher bribes and higher corruption, exit rates are higher; on the other hand where legal rights are weak, financial services less developed and competition is muted, exit rates are lower.

\section{Corruption and Investment}

Some commentators have argued that corruption may be beneficial in environments which have been distorted through ill-functioning institutions. In effect, corruption confers benefits to business through 'greasing the wheels' and lowering transaction costs (Huntington, 1968; Leff, 1964; Meon \& Sekkat, 2005). Others argue that corruption is itself distortionary. It 
increases perceived levels of environmental uncertainty (Shleifer \& Vishny, 1993; Wei, 1997); it 'sands the wheels'. In highly fluid institutional settings, this is arguably more likely, making the unpredictable even more so. However, this arises not simply from the presence of corruption per se, but to how corruption manifests (Cuervo-Cazurra, 2008). The contribution of corruption to perceived levels of environmental uncertainty is underpinned by a number of factors, of which pervasiveness - corruption that is certain and widespread, and arbitrariness corruption that is uncertain, are key dimensions (Cuervo-Cazurra, 2008; Lee \& Oh, 2007; Rodriguez, Uhlenbruck, \& Eden, 2005; Uhlenbruck, Rodriguez, Doh, \& Eden, 2006; Wei, 1997). The pervasiveness of corruption is seen as more of a deterrent to the initial investment decision because it increases the known costs of investing. In contrast, when corruption is unknown or unpredictable, in other words, arbitrary, it does not act as such a deterrent to investment because it is perceived as part of the uncertainty of operating a new market (Cuervo-Cazurra, 2008).

Our study follows previous studies, in distinguishing between the two dimensions underpinning government corruption, namely, arbitrariness and pervasiveness (Lee \& Oh, 2007; Meschi, 2009; Rodriguez, et al., 2005). We disaggregate the impact of government corruption on the reinvestment decision by focusing upon the influence of both pervasive and arbitrary corruption in the institutional context of the transitional periphery.

**************** INSERT FIGURE 1 HERE*******************

\section{Corruption and Reinvestment}

In making strategic decisions about reinvestment, incumbent MNEs have additional knowledge of the institutional environment gained through their operating experience post entry. This is particularly important with respect to pervasiveness as it means that the level of 
uncertainty regarding this dimension has decreased and, therefore, managers are less likely to misjudge or ignore the costs (Doh, et al., 2003). Consequently, their knowledge in coping with pervasive levels of corruption is likely to be well developed. In effect, their market experience has mitigated their liability of foreignness (Zaheer, 1995) with respect to corruption. Either they know with which third parties they need to negotiate, and in what manner or, they are apprised of the potential consequences of non-engagement with these third parties. The former may derive from an isomorphic process over time, encompassing coercive and mimetic elements (DiMaggio \& Powell, 1983), whilst the latter may relate to a specific ethical stance (Bondy and Starkey 2014), supra-national conventions or country of origin legal constraints (e.g. the American Foreign Corrupt Practices Act 1977, OECD Convention on Bribery of Foreign Public Officials in International Business, 1997 and 2009, UK Bribery Act 2010). However, the institutional embeddedness of the firm may offer less benefit to the organisation where corruption is characterised by arbitrariness. By arbitrariness we mean the degree of uncertainty and capriciousness associated with public sector corruption (Uhlenbruck, et al., 2006:403). For example, there is evidence to suggest that firms which interact more extensively with public sector institutions and are subject to a higher bureaucracy burden and more inspections, are likely to bribe more (Nur-Tegin \& Sahin, 2013). However, where bureaucrats co-ordinate and organise their activities, bribery levels are lower (Blackburn \& Forgues-Puccio, 2009). This finding supports the 'grabbing hand' perspective which emphasises the negative impact arising from the unpredictability associated with independent bureaucrats soliciting bribes in pursuit of their own agendas (Frye \& Shleifer, 1997; Shleifer \& Vishny, 1998). Nonetheless, there is significant difference in the impact of corruption upon firms investing in transitional economies (Cuervo-Cazurra, 2008). In making the initial FDI decision in this context, there is evidence to suggest that firms prefer to deal with the uncertainty around arbitrary corruption rather than the more predictable pervasive corruption. Managers view arbitrary corruption as one part of the endemic 
uncertainty that underpins the institutional structures supporting business transactions in transitional economies (Cuervo-Cazurra, 2008:13). Although, pervasive corruption also has a negative influence, it represents a known, additional and, ongoing, cost. In transitional economies, the additional unpredictable transaction costs which corruption represents "may be compensated by the benefits that it provides in terms of bypassing regulations and institutions that were designed for a previous system but have not yet been dismantled" (Cuervo-Cazurra, 2008:15). We follow the author's argument about the contingent nature of the impact of corruption, and extend this underlying institutional rationale in the reinvestment decision. We argue that in countries where institutional arrangements are particularly fluid, the negative consequences of corruption will be more pronounced. Hence, such countries will constitute less attractive reinvestment destinations than the "core" transitional economies of Eastern and Central Europe which have attained EU membership.

Hypothesis 1: Greater perceived arbitrary corruption is negatively related to reinvestment by the MNE subsidiaries.

Bribery is one significant aspect of corruption (Lee, Oh and Eden, 2010) and, where commonplace and endemic, it is a key indicator of pervasive corruption. The soliciting, and payment, of bribes illustrates the weakness of institutions which, in turn, can lead also to the inadequate enforcement of legal contracts. Pervasiveness of corruption has been defined as the likelihood of the average firm encountering corruption in its normal interactions with state officials (Rodriguez, Uhlenbruck, \& Eden, 2005; Uhlenbruck et al, 2006). These corrupt interactions are generally manifest by implicit and/or explicit demands for payments or bribes. 
Laws against bribery abroad, such as the OECD Anti-Bribery Convention (2009) or the more recent 2010 Bribery Act in the UK, aim to reduce the supply of bribes by foreign investors by increasing the costs of bribing abroad (Cuervo-Cazurra, 2008). In other words, anti-bribery laws act as a disincentive to engaging in corruption in host countries (Cuervo-Cazurra, 2006). In his study, whilst Hines (1995) did not find an overall negative correlation between corruption and inward FDI, he did find that American business activities in bribe-prone countries decreased sharply after the enactment of the U.S. Foreign Corrupt Practices Act (1977). However, Spencer \& Gomez (2010) reported more mixed results with respect to MNEs from home countries which were signatories to the OECD Convention. Having said that, there is evidence that an MNE's readiness to pay bribes is lowest when such illicit activities are not tolerated in its home country (Baughn, Bodie, Buchanan, \& Bixby, 2010). Even if firms continue to transact business in countries riven with bribery, but do not engage in such practices, they are likely to find themselves disadvantaged in comparison to competitors who do pay bribes. In the longer term, should companies engage in bribery, they may find themselves subject to other direct and indirect costs. Illustrating the potential significance of such costs is the case of the defence contractor BAE which was reported to have agreed to pay out $\$ 450 \mathrm{~m}$ to US authorities in penalties over alleged corporate bribery as well as $£ 30 \mathrm{~m}$ in UK fines (Peel, 2010; Peel \& Kirchgaessner, 2010) and that of UK based publisher Macmillan which was debarred from any World Bank financed contracts for a period of six years after admitting bribery payments relating to a Trust Fund-supported education project in Southern Sudan (World Bank, 2010).

It could be argued that these cases represent exceptions to a general rule, and there are many instances where firms have engaged in corrupt behaviour with relative impunity, an example being BAE's role in a major Saudi arms deal. However, on a day to day level, firms that pay more in bribes are likely to spend more time negotiating regulations with foreign countries' 
officials (Kaufmann \& Wei, 2000); another layer of cost. In contexts where corruption is pervasive, competing factions and different levels of official may each express their own demands for making the same transaction possible; in such circumstances a "rational corrupt agent may (readily) extinguish the source of his bribe income by causing a firm to exit" (Bliss \& Tella, 1997:1001). So, firms operating in countries with high levels of bribery are likely to find their costs are increased irrespective of whether or not they actually pay bribes, and these costs can extend beyond the short term.

H2: Greater perceived pervasive corruption is negatively related to reinvestment by the MNE subsidiaries.

\section{Judicial Institutions and Reinvestment}

Quality of government (Holmberg, Rothstein, \& Nasiritousi, 2009) and specifically 'good governance within each country' is vital in aiding development and fostering economic growth (United Nations, 2000:13). Given that institutions provide the context within which the firm's transactions take place, it is to be expected that a number of scholars have noted the importance of positive and robust host government institutions (Henisz, 2000; Meyer, 2001). Within the economics and finance literature, priority is accorded to private property rights (La Porta, et al., 1999, 2002). Mirroring this, the 'Rule of law' constitutes one of the World Bank's six Worldwide Governance Indicators (Kaufmann, Kray, \& Mastruzzi, 2007). Confidence in the ability to capture rents is inherently linked with managerial perceptions of the host country's legal institutions to provide adequate safeguards against arbitrary rulings as well as shaping an environment in which wrongdoers are captured and punished (Roy \& Oliver, 2009). 'Administrative quality' in the form of control of corruption as well as the investment-friendly profile of administration, law and order is an important influence in decisions about resource commitment (Aysan, Nabli, \& Veganzones-Varoudakis, 2007), with 
strong legal institutions critical in securing property rights and integrity of contract (Haggard, MacIntyre, \& Tiede, 2008).

Arguably, firms are unlikely to commit further resources in markets, even low-risk internally generated finance, where they property rights are not respected and contracts are unenforceable. Reinvestment is likely to take place within an environment in which the firm is confident that this financial commitment can be protected by legal recourse, if necessary. The judicial system provides "coercive enforcement" of agreements (North, 1990:362) and therefore the efficiency of the judicial system is critically important (Mauro, 1995), and drive reinvestment choices. As the World Bank Enterprise Survey data indicates (Mellahi, Demirbag and Wood, 2012), among transitional institutions, weak legal institutions are more likely to be encountered on the periphery, and this is the primary determinant of lower levels of reinvestment among transitional peripheral states.

H3: Greater perceived quality of judicial institutions is positively related to reinvestment by the MNE subsidiaries.

\section{Reinvestment and Length of Operations}

MNEs with a longer tenure of operations within a particular context are more likely to make additional investments (Mudambi, 1998). Through longevity, the firm may develop experience-based capabilities, refined routines and the ability to adapt (Baum \& Shipilov, 2006; Henderson, 1999). Such skills are of even greater value in environments characterised by high degrees of uncertainty within the institutional domain. Over time, organisations have the opportunity to build networks and relationships with institutions (Hoskisson, Eden, Lau, \& Wright, 2000) thereby reducing the negative impacts of corruption on transactions costs (Makhija, 2003; Makhija \& Stewart, 2002). Age can confer specific advantage in terms of the 
institutional embeddedness of the organisation leading to a reduction in perceptions of institutional uncertainty resulting from corruption, or the opportunity to manipulate the environment to match its needs (Zimmerman \& Zeitz, 2002), so, for example, older firms may have developed greater bargaining power leading to public officials demanding fewer bribes (Svensson, 2003). At the most basic level, those older firms actively participating in corruption know who to pay and, how much. Similarly experienced firms, not actively engaging in corruption, understand the likely impacts and are therefore in the optimal position to make judgements regarding cost implications. Hence, whilst transitional peripheral economies are more challenging environments in which to do business than the core post state socialist economies, it could be argued that any differences in reinvestment choices between these two sets of countries will be less pronounced among firms that have been established for longer.

H4a: The length of an MNE's operation in a host country is positively related to its reinvestment in the same host country.

H4b: Any differences in levels of reinvestment between transitional peripheral, and other post state socialist, economies will be less pronounced among firms that have been domiciled for longer.

\section{Reinvestment and Size of Operation}

Larger firms have greater resources available to them than smaller firms and therefore are better able to pay bribes (Svensson, 2003). Increased size also provides advantages such as enhanced contacts, 'clout' and the ability to make credible threats of retaliation to host governments should property rights be violated (Acs, Morck, Shaver, \& Yeung, 1997). The impact of corruption is greater for small and medium sized enterprises (SMEs) than for large MNEs (Beck, Demirguc-Kunt \& Maksimovic, 2005). Further, SMEs are more sensitive to the 
heightened uncertainty and levels of risk which are characteristic of corrupt institutional domains (Ghosal \& Loungani, 2000; Lskavyan \& Spatareanu, 2008) and consequently they are less likely to commit additional resources through reinvestment. Thus, it could be argued that any differences in reinvestment choices between core transitional and transitional peripheral economies will be less pronounced in the case of larger firms.

H5a: The size of an MNE's operation in a host country is positively related to its reinvestment in the same host country.

H5b: Any differences in levels of reinvestment between transitional peripheral, and other post state socialist, economies will be less pronounced as firm size increases.

It has been argued that, for firms operating in transitional economies, there is a trade-off between the advantages provided by corruption in navigating a reforming and weak institutional domain and concomitant uncertainty and additional transaction costs (CuervoCazurra, 2008). Consequently, corruption does negatively influence the FDI decision, but the impact is less pronounced in transitional economies, in comparison to developed economies. However, innovating firms in developing markets pay more bribes (Ayyagari, DemirgüçKunt, \& Maksimovic, 2014). Examples of innovation include upgrading a product line, introducing new technology or signing new joint ventures - activities which require reinvestment by the firm. Such activities necessitate additional engagement with public officials thereby increasing the opportunity for the solicitation of further payments and bribes by government officials in an organised manner, typical of pervasive corruption. Moreover, bribe payments have been found to be higher under more decentralized bureaucratic structures (Diaby \& Sylwester, 2014). It is credible to argue such structures are more likely to be found in contexts where institutions are sufficiently weak, or fluid, to allow actors to disengage, 
fully or partially, from the centre (Wood \& Lane, 2012). This in turn increases the potential for arbitrary corruption. Consequently, we argue that:

H6a -Pervasive corruption has a larger negative impact on reinvestment decisions on transitional peripheral, than on other post state socialist, economies.

H6b - Arbitrary corruption has a larger negative impact on reinvestment decisions on transitional peripheral, than on other post state socialist economies

\section{METHODS}

This study draws upon the World Bank Enterprise Survey Data and utilises a sample of 27 countries from Eastern Europe and Central Asia, of which (more than 5\%) belong to a foreign investor (www.enterprisesurveys.org/). The World Bank Enterprise Survey is designed to collect firm level data on a broad range of issues that firms face. The survey is based on a stratified random sampling which covers firms of different size, industry, ownership, country of origin, and geographical location (for more details see Table 1). The Enterprise Survey covers a wide range of global issues, many of those particularly relevant to transitional and emerging countries around the world. Issues covered in the survey include financing of SMEs, human resources, technology development, corruption, crime, and infrastructure and other issues relevant to business environment. (For a detailed explanation of the sampling method of the enterprise survey see, http://www.enterprisesurveys.org/, Uhlenbruck and Rodrguez et al., 2006; Sahadev and Demirbag, 2011; Gomes, Sahadev, Glaister and Demirbag, 2014).

Transitional periphery countries constitute $53.7 \%$ of the sample and a breakdown is reported in Table 1. Transitional EU members in the sample are Hungary (9.3\%), Poland (7.4\%), 
Estonia (4.0\%), Czech Republic (3.3\%), Slovakia (2.6\%), Latvia (2.5\%), Lithuania (2.5\%) and other post soviet EU members (14.7\%).

\section{[Insert Table 1 here]}

Missing values and outliers have been removed from the original data in order to render a clean dataset for analysis. Since the focus of this study is to examine factors affecting MNEs' reinvestment in countries at the transitional periphery, all non MNE entries were also removed from the dataset.

\section{Measurement of variables}

Dependent and independent variables are measured as follows:

Dependent variable (REINVEST): The log of re-investment is in US dollar by the firm. Reinvestment covers items such as new building, machinery and equipment.

\section{Independent variables}

Judicial institutions: This is based on respondents' perception of courts in countries where these subsidiaries are located, thus the state of the court system in a host country is used as proxy for legal institutions. Three different dimensions of legal institutions are treated as dichotomous variables. A value of 1 is ascribed to the state of a court system if it was perceived as being to a great extent fair and impartial (IMPARTIAL); 0 otherwise. Similarly, the court system is given the value of 1 if perceived as being to a great extent honest and uncorrupt (UNCORRUPT); 0 otherwise. Finally, the ability of court systems to enforce its decisions is the third dimension of legal institutions (ENFORCE) and it has the value of 1 if it was perceived that the court system can enforce its decisions in resolving business disputes to a great extent; 0 otherwise. 
PERVASIVE, Pervasiveness of corruption is measured on a 6 point scale according to whether it was common for firms in its line of business to pay some irregular "additional payments/gifts" to get things done with regards to customs, taxes, licences, regulations, services etc.

ARBITR (Arbitrariness): Arbitrariness of corruption in host countries is measured by respondents' perception of government agents acting within rules without unofficial recourse to any financial or social gains. The variable aims to measure whether another official or superior intervenes, without unofficial recourse to financial or social gains, when government agents act against the rules. The perceived level of arbitrariness is measured by a 6 point reverse measurement where 6 is never and; 1 is always.

$A G E$ : Subsidiary age is measured by Logarithm of years of subsidiary's operations in a country.

SIZE: Size is measured by Logarithm of number of permanent, full time firm employees.

Regional impact

TRANSPERI: Host countries MNE Subsidiaries' are classified as a dummy variable where 1 is Transitional Periphery; 0 is otherwise.

\section{Control Variables}

Parent level controls:

DC MNE: Country of origin of MNEs are classified as DC MNE is 1, if the country of origin was a developed country; 0 otherwise.

EMNE: Country of origin of MNEs are classified as EMNE is 1, if the country of origin was an emerging country; 0 otherwise. 


\section{Industry level controls}

The sample comprises 5 major sectors. These are:

MANUFACT: Manufacturing

TRADE: Wholesale and retail trade

CONSTRUCT: Construction and real estate

HOSPITALITY: Hotels and hospitality industry

OTHER SERVICES: This is used as the base dummy.

\section{ANALYSIS RESULTS}

We test hypotheses by linear regression analyses to determine the impact of hypothesised variables on log transformation of reinvestment by MNEs' subsidiaries in respective host countries. Any multicollinearity problems were checked before running regression analysis. Table 2 shows the binary correlations between variables used in regression models.

[Insert Table 2 here]

The variance inflation factor (VIF) is less than 2.9 for all the variables included in the analysis, except for sector dummy. Both pairwise correlations and VIFs are at acceptable levels. This shows the lack of multicollinearity (Hair et al., 2006). We use linear regression models to test hypothesized relations. (Results from linear regression analyses are shown in Table 3 and 4 . The F statistics indicate that all five models in Table 3 are significant. The results from a subgroup regression analysis were used to test hypotheses 4 and 5 (Table 4). Table 4 shows that all three sets of models (Models 1 to 3 ) have high explanatory power with significant $\mathrm{F}$ values $(57.76 ; 24.69 ; 38.49$ at $\mathrm{p}<.001$ respectively). As indicated in Table 4, all models have a good fit with adjusted $\mathrm{R}^{2}$ measures confirming explanatory power of models 
presented to examine impact of subsidiary age and size on reinvestment between firms investing in transitional periphery counties (classified as 1) and others (classified as 0 ).

[Insert Table 3 here]

[Insert Table 4 here]

In order to test the study's hypotheses $1,2,3,4 \mathrm{a}, 5 \mathrm{a}, 6 \mathrm{a}$ and $6 \mathrm{~b}$, four regression models are estimated with the dependent variable being MNEs' re-investment (REINVEST). Hypotheses $4 \mathrm{~b}$ and $5 \mathrm{~b}$ are tested by subgroup models for transitional periphery and post-Soviet EU economies with dependent variable being reinvestment. Results of subgroup regression analyses are presented in Table 4. A summary illustration of variables, hypothesised relations and directions of hypotheses are presented in figure 1.

In the first model in Table 3 (Model 1), two sets of control variables and the regional variable (TRANSPERI) are introduced. Model 2 however, introduces independent variables judicial institutions related variables (IMPARTIAL, UNCORRUPT, and ENFORCE), and two dimensions of corruption (PERVASIVE and ARBITR). Interactions of corruption dimensions with transitional periphery are presented in Model 4 while the final model (Model 5) tests impact of corruption dimensions and judicial institutions on reinvestment decisions of MNEs (full model).

The first hypothesis receives very significant support both in Models 2 and 5 with a negative sign, indicating that when there exists arbitrary corruption, MNEs are less likely to reinvest in the respective host countries. Hypothesis 2 (pervasiveness of corruption) however receive statistically significant support only in the final model when the interaction with the transitional periphery is introduced. 
The results presented in Model 2 in Table 3 indicate that whilst arbitrariness of corruption has a negative effect, an honest and uncorrupted court system (UNCORRUPT) has a positive effect on the reinvestment decisions of MNEs. Therefore, the third hypothesis receives only partial support as the coefficient for only one dimension of judicial institutions is significant, but not for the others. While having an "honest and uncorrupted" court system has a positive and significant impact on reinvestment decisions, "fairness and impartiality" and "ability to enforce decisions" does not emerge as statistically significant. Taking all these three measures together, the relationship between re-investment and judicial institutions indicates that the there is a positive relationship between the quality of judicial environment and re-investment decision in a host country.

What is surprising, however, is that the pervasiveness of corruption in host countries (Hypothesis 2) did not receive meaningful support in terms of its impact on the level of reinvestment. Although the coefficient has a negative sign, this is not a statistically significant one in Model 2. We further examine both arbitrariness and pervasiveness of corruption's impact by analysing their interaction effect for transitional periphery. Although the level of pervasiveness of corruption does not emerge as significant in Model 2, the interaction effect for transitional periphery yields negative, and statistically significant, results. The interaction effect of transitional periphery with PERVASIVE and ARBITR increase their impact in the final model as negative and significant (in Model 5), indicating that pervasiveness and arbitrariness of corruption perception of executives in transitional periphery negatively affects re-investment decisions of MNEs in the transitional periphery (compared to EU member transitional countries). The coefficients of interactions of pervasiveness (PERVASIVE) and arbitrariness (ARBITR) of corruption with transitional periphery are both negative and significant in the final model providing significant support to hypotheses 6a and 6b. While 
arbitrariness of corruption has a very strong negative impact on reinvestment at transitional periphery $(\beta=-0.06 \mathrm{p}<0.01)$, there is a relatively less significant impact of pervasiveness for transitional periphery countries $(\beta=-0.05 \mathrm{p}<0.10)$.

Subsidiary size appears to be a significant factor in MNE re-investment decisions. Regression models presented in Table 3 indicate that the larger the size of a subsidiary, the greater the likelihood of a decision to re-invest in a host country. The impact of the length of operation (AGE) and the size of operation (SIZE) were tested in model 5 in Table 3. Both the length of operation and the size of MNE subsidiary are significant factors in determining the percentage reinvestment undertaken by MNEs. The regression coefficients associated with the AGE and SIZE are statistically significant ( $\mathrm{p}<0.05$ and $\mathrm{p}<0.01$ respectively) providing support for $\mathrm{H} 4 \mathrm{a}$ and $\mathrm{H} 5 \mathrm{a}$.

Hypotheses $4 \mathrm{~b}$ and $5 \mathrm{~b}$ are tested by a set of subgroup regression models presented in Table 4. Model 1 in Table 4 introduces a full model for reinvestment (REINVEST) as dependent, AGE and SIZE as independent with control variables, whilst in Models 2 and 3, two subgroup regression models are estimated for the transitional periphery and post-Soviet EU countries respectively. Model 1 in Table 4 shows regression results for the full sample. Both AGE and SIZE have positive and statistically significant impact on reinvestment for the full sample. In Models 2 and 3 however, we test impact of SIZE and AGE on reinvestment in transitional periphery and post-Soviet EU countries as subgroups. SIZE emerges as a significant factor for both subgroups while AGE emerges significant only for post-Soviet economies. For the second stage of the subgroup analysis to test $\mathrm{H} 4 \mathrm{~b}$ and $\mathrm{H} 5 \mathrm{~b}$, we employ the Chow test for the statistical significance of difference in the regression coefficients between the subgroups of countries in the sample. The $\mathrm{F}$ value for the Chow test $F_{\text {Chow } T}=5.436$ is significant $(\mathrm{p}<0.001$; 
d.f. 9) which implies that the difference between the regression coefficients for these two groups is statistically significant ${ }^{1}$.

In general AGE receives significant support in our linear regression analysis (Table 3). The age of operations in a host country is used as proxy for the level of business experience and embeddedness in a locale. We find that as an MNE is experienced in a locale, the likelihood of re-investment increases significantly. The subgroup regression model presented in Table 4 (Model 2b) however, indicates that the impact of AGE on REINVESTMENT is more pronounced for core transitional economies compared to transitional periphery. Since the hypothesis does not expect significant difference between these two groups, there is a lack of support for $\mathrm{H} 4 \mathrm{~b}$.

Regarding the difference on the impact of SIZE on REINVESTMENT between core transitional and peripheral economies, there is a support for $\mathrm{H} 5 \mathrm{~b}$ as the size impact in both sub-groups are very close $(\beta=0.680 \mathrm{p}<0.001$, and $\beta=605 \mathrm{p}<0.001$ indicating that any reinvestment difference between these two group of countries will be less pronounced as subsidiary size increases.

Amongst sectoral controls, only TRADE (service industries) and CONSTRUCTION have negative, and statistically significant, coefficients which implies a lower propensity to reinvestment by MNEs in these industries. In terms of country of origin of MNEs, developed country MNE subsidiaries (i.e., subsidiaries of the US, UK, Canada or Japanese MNEs) are more likely to reinvest and expand the size of their operations. However, its coefficient in the final model is not statistically significant. Regional control of transitional periphery has

\footnotetext{
${ }^{1}$ We also applied the dummy variable method to validate the Chow test results which is not reported in this paper.
} 
negative, and significant, coefficients in all of the models presented in Table 3. This indicates a lower propensity to reinvest in Transitional Periphery countries in comparison to EU member transitional countries.

\section{FINDINGS AND CONCLUSIONS}

We find that reinvestment rates are lower on the transitional periphery than in other post state socialist countries. But, what precisely, makes transitional peripheral countries less attractive? Our findings suggest relative perceptions of corruption are particularly severe deterrents to reinvestment in the transitional periphery, but not in the "core" post-state socialist transitional economies. It is likely that this reflects the greater institutional fluidity within such contexts, making for a more unpredictable business environment. In other words, bribery and corruption may be easier to cope within climates where there is a greater predictability and continuity. These findings extend previous studies which have focused upon the deterrent effect of pervasive corruption upon FDI, but which looked at the initial investment decision only.

It has been argued that the effects of corruption on investment will be more pronounced once firms have a greater understanding of the costs it poses (Cuervo-Cazurra, 2008). However, our results also show that, whilst age is statistically significant, older firms are more likely to reinvest. At first glance, this may appear counter-intuitive in light of the strength of the negative influence of pervasiveness. However, it may be that this actually reflects greater organisational embeddedness within local networks, which allows firms to link with each other, and with government and other players, and/or, greater experience and accumulated wisdom in dealing with a range of adverse contexts. 
A robust court system is an important part of strong institutions (Djankov, La Porta, LopezDe-Silanes, \& Shleifer, 2003). Our data partially supports this argument and indicates that legal institutions are important for reinvestment, particularly an honest and uncorrupted judicial system. However, issues around contract enforcement, such as fairness and impartiality and the ability to enforce decisions, are not perceived as important by managers. To a degree, these findings resonate with the equally mixed evidence provided by Beck, Demirguc-Kunt \& Maksimovic (2005) in their analysis of legal constraints on firm growth. Equally, our findings with respect to enforcement may indicate the bargaining power that MNEs have by virtue of size and importance of FDI to the host. Nonetheless, this is an interesting finding which merits further research, given that previous work has suggested that higher levels of FDI inflows are associated with low cost contract dispute settlement environment (Alqhuist \& Prakash, 2010).

With respect to organizational size, our findings also support Bercovitz and Mitchell's (2007) contention that scale is an important variable for long-term business survival in uncertain environments because of the organizational capital that it provides. Whilst their study integrated scale (using sales revenue) and scope, the focus of our study has allowed us to examine the relationship between reinvestment and size in endemically uncertain institutional environments more narrowly. They argue that to use sales and proxy for size, simply picks up profitability effects. We avoid this by utilising the number of employees as proxy. From a methods standpoint, our use of micro-data together with the actual experience of working MNE managers means that we avoid any distortionary effects arising from the use of perception-based indices (Aidt, 2009). Again, we find that size is a particularly important factor on the transitional periphery; quite simply, larger firms with greater resources at their disposal are better equipped to ride out environmental turbulence. 
It could be the case that firms engaged in primary commodity sectors will be less sensitive to institutional weakness and fluidity than those in other sectors, owing to increasing resource scarcity and costs. However, we do not find that sector is a significant variable, other than in the case of the service and construction sectors. Construction is a bellweather industry, and more prone to the effects of any economic downturn. Furthermore, the proliferation of low cost Chinese competitors, which rely on their own imported labour, has made the international business environment more challenging. Again, service sector activities may require a greater engagement with a broad range of local players (labour, customers and suppliers) than in other sectors, where it may be possible to do lucrative business with a small socio-economic footprint.

\section{Contributions}

Our study has important implications for both policy and practice. From a policy perspective, reinvested earnings are an important part of maturing FDI stocks (Lundan, 2006). Through reinvestment MNEs grow their affiliates, thereby increasing their direct contribution to national growth and prosperity through tax revenue and employment. However, MNE reinvestment is also vital as part of growth, $R \& D$ and innovation processes, which although internally focused by the MNE, can have important spillover effects enhancing technological enhancement within the host country (Blomström \& Kokko, 1998; Eden, Levitas, \& Martinez, 1997; Meyer \& Sinani, 2009; Ozawa, 2009). Host governments should seek to encourage reinvestment by incumbents as they represent less high risk than new FDI, and contribute to greater stability in FDI flows (Lundan, 2006, Mudambi, 1998). Our core finding is that institutional setting, and more specifically, relative institutional fluidity accentuates any adverse consequences of bribery and corruption on reinvestment choices, and that, host governments need to temper reform with the need for predictability. In other words, legal origins appear to be less important than how institutions work in practice; this highlights the 
limitations in basing investment decisions on formal property rights, without due consideration as to how they are being implemented in practice.

From a managerial perspective, our study suggests that managers should give careful consideration to the degree and allocation of reinvestment funds in order to achieve optimal results. Managers need to explicitly recognise any trade-offs made between growth and innovation, and the security of that investment when they make reinvestment decisions. Furthermore, reinvesting into the business potentially provides added levels of financial slack which can be a critical factor in protecting a firm , and ensuring its survival, from the impact of environmental jolts (Bradley, et al., 2011). Larger and more experienced firms are better equipped to cope with environmental uncertainty; greater organisational resources and the accumulated knowledge and wisdom makes doing business in uncertain environments more easy.

To date, many scholars have explored the question of how corruption affects FDI with multifarious results. We have contributed to the debate through our novel focus on an underresearched aspect of FDI, namely, earnings reinvestment. Methodologically, we have explored this relationship within an integrated multi-level perspective. In this way, we have added to different bodies of empirical research, firstly; the small but growing body of empirical data which combines micro data across country and secondly; an emerging conceptual approach which fuses micro organisational factors with macro governance influences drawing on institutional theory. The breadth of the country of origin of the firm sample also merits highlighting as there is only limited comparable work which has drawn upon a range of countries focused upon small businesses in emerging economies (Chhakravarty \& Xiang, 2011). Other empirical work in this area focused upon post- 
communist countries (Johnson, et al., 2002) and Chinese firms in 2002 (Cull \& Xu, 2005). Arguably these represent atypical phenomena of countries in transition, and as such it is not surprising that the security of property rights would be of high managerial concern. Our sample allows a more rounded picture to emerge in this respect as it draws upon data from both transitional-EU members, as well as transitional periphery. Our findings regarding the significant influence of pervasive corruption on reinvested earnings is novel but builds upon previous evidence on its influence on the initial MNE investment commitment. Our study indicates that there are further areas of the relationship between corruption and MNE reinvestment which warrant further investigation. This includes a deeper exploration of reinvestment over time and the nature of the link between reinvestment and resource allocation and innovation as well as further unpicking of the influence of contract enforcement.

There are also limitations of the paper. Firstly, while the dataset used in this study is created by a professional organisation using a standard scale across nations, there are inherent limitations in such global surveys. However, our study provides some important pointers for the future and contributes to an emerging body of literature. Secondly, this paper focuses on two groupings of countries only, therefore a larger study including larger emerging countries would enhance existing body of literature. Thirdly, some of the scales used by the enterprise survey have a focus on only certain dimensions of quality of judicial institutions. 
Table 1. Characteristics of the Sample

\begin{tabular}{|l|c|c|}
\hline Sample characteristics & No & \% \\
\hline Broad country of origin of MNEs & 580 & 56.8 \\
Developed Country MNEs & 157 & 15.4 \\
Emerging Country MNEs & 234 & 22.9 \\
Transitional Country MNEs & 50 & 4.9 \\
Other (Mixed) & & \\
\hline Subsidiary size (number of employees) & 481 & 47.1 \\
Small size (Less than 50) & 313 & 30.7 \\
Medium size (50 to 249) & 227 & 22.2 \\
Large size (More than 250) & & \\
\hline Subsidiary age (years) & 512 & 50.2 \\
Young firms (Less than 10) & 375 & 36.7 \\
Middle age firms (10 to 19) & 134 & 13.1 \\
Mature firms (More than 20) & & \\
\hline Ownership mode of subsidiary & 566 & 55.4 \\
Joint venture & 455 & 44.6 \\
Wholly owned subsidiary & & \\
\hline Industry of subsidiary & 16 & 1.5 \\
Mining & 41 & 4.0 \\
Construction & 496 & 48.6 \\
Manufacturing & 70 & 6.9 \\
Transport, storage and communication & 249 & 24.5 \\
Wholesale and retail trade & 82 & 8.0 \\
Real estate, renting and business services & 52 & 5.1 \\
Hotels and restaurants & 15 & 1.4 \\
Other services & 24 & 2.4 \\
\hline Host countries (Transitional Periphery) & 36 & 3.5 \\
Albania & 51 & 5.0 \\
Armenia & 42 & 4.1 \\
Azerbaijan & 31 & 3.0 \\
Belarus & 29 & 2.9 \\
Bosnia & 4.6 \\
Georgia & $\mathbf{1 0 2}$ \\
Moldova & & \\
Kazakhstan & & \\
Kyrgyzstan & & \\
Tajikistan & & \\
Uzbekistan & & \\
Other transitional periphery & & \\
\hline Total & & \\
\hline
\end{tabular}


Table 2. Descriptive Statistics and Correlations among Variables

\begin{tabular}{|c|c|c|c|c|c|c|c|c|c|c|c|c|c|c|c|c|c|c|}
\hline Variable name & Definition & Mean & S.D. & 1 & 2 & 3 & 4 & 5 & 6 & 7 & 8 & 9 & 10 & 11 & 12 & 13 & 14 & 15 \\
\hline 1. REINVEST & Log of reinvestment & 1.59 & 0.70 & 1.00 & & & & & & & & & & & & & & \\
\hline 2. IMPARTIAL & Impartial court system & 0.32 & 0.46 & 0.18 & 1.00 & & & & & & & & & & & & & \\
\hline 3. UNCORRUPT & Uncorrupt court system & 0.31 & 0.46 & $0.22 *$ & $0.59^{*}$ & 1.00 & & & & & & & & & & & & \\
\hline 4. ENFORCE & Enforcing court decisions & 0.41 & 0.49 & 0.15 & $0.45^{*}$ & $0.44 *$ & 1.00 & & & & & & & & & & & \\
\hline 5. PERVASIVE & Pervasiveness of corruption & 2.42 & 1.46 & -0.15 & -0.19 & $-0.22 *$ & -0.08 & 1.00 & & & & & & & & & & \\
\hline 6. ARBITR & Arbitrariness of corruption & 0.73 & 0.44 & $-0.17 *$ & $-0.23^{*}$ & $-0.26^{*}$ & $-0.21 *$ & 0.13 & 1.00 & & & & & & & & & \\
\hline 7. TRANSPERI & Transitional periphery location & 1.74 & 0.71 & $-0.28 *$ & -0.16 & $-0.17^{*}$ & -0.07 & 0.16 & 0.11 & 1.00 & & & & & & & & \\
\hline 8. SIZE & Log of subsidiary employees no & 1.00 & 0.31 & $0.60^{*}$ & 0.11 & 0.10 & 0.09 & -0.08 & -0.07 & 0.02 & 1.00 & & & & & & & \\
\hline 9. AGE & Log of subsidiary age & 0.47 & 0.49 & $0.38 *$ & 0.03 & 0.12 & 0.03 & -0.11 & -0.07 & -0.10 & $0.32 *$ & 1.00 & & & & & & \\
\hline 10. DCMNE & DCMNE parent & 0.55 & 0.49 & 0.16 & 0.08 & 0.09 & 0.05 & -0.08 & -0.01 & $-0.28 *$ & 0.06 & -0.02 & 1.00 & & & & & \\
\hline 11. EMNE & ECMNE parent & 0.14 & 0.35 & $-0.18 *$ & -0.05 & -0.05 & 0.00 & 0.08 & 0.05 & $0.28^{*}$ & -0.04 & -0.06 & $-0.46^{*}$ & 1.00 & & & & \\
\hline 12. MANUFACT & Manufacturing & 0.46 & 0.49 & $0.29 *$ & 0.06 & 0.03 & 0.05 & -0.02 & -0.01 & 0.03 & 0.31 & 0.15 & 0.02 & 0.03 & 1.00 & & & \\
\hline 13. TRADE & Wholesale and retail. & 0.25 & 0.43 & $-0.31 *$ & -0.06 & -0.03 & -0.06 & 0.06 & 0.03 & 0.00 & -0.08 & -0.15 & -0.02 & -0.03 & $-0.54 *$ & 1.00 & & \\
\hline 14. CONSTR & Construction & 0.12 & 0.32 & -0.09 & -0.01 & -0.02 & 0.00 & 0.01 & -0.00 & 0.03 & 0.08 & -0.05 & -0.03 & 0.02 & $-0.34 *$ & $-0.21 *$ & 1.00 & \\
\hline 15. HOSPTY & Hospitality & 0.05 & 0.22 & 0.06 & 0.04 & 0.04 & 0.07 & -0.06 & -0.06 & -0.02 & -0.01 & 0.08 & 0.00 & 0.00 & $-0.21 *$ & -0.13 & -0.08 & 1.00 \\
\hline
\end{tabular}

Notes:

S.D. = Standard deviation

$* \mathrm{p}<0.01$ 
Table 3. Linear Regression Results (Dependent Variable: REINVEST)

\begin{tabular}{|c|c|c|c|c|c|c|}
\hline & & Model 1 & Model 2 & Model 3 & Model 4 & Model 5 \\
\hline Variable name & Definition & $\beta$ & $\beta$ & $\beta$ & $\beta$ & $\beta$ \\
\hline \multicolumn{7}{|c|}{ Host country level independent variables } \\
\hline IMPARTIAL & Impartial court system & & $-0.03(0.10)$ & & & $-0.06(0.08)$ \\
\hline UNCORRUPT & Uncorrupt court system & & $0.25 * *(0.10)$ & & & $0.13 * *(0.08)$ \\
\hline ENFORCE & Enforcing court decisions & & $0.10(0.07)$ & & & $0.02(0.05)$ \\
\hline PERVASIVE & Pervasiveness of corruption & & $-0.04(0.02)$ & & & $-0.08 * *(0.04)$ \\
\hline ARBITR & Arbitrariness of corruption & & $-0.13 * *(0.08)$ & & & $-0.24 * *(0.12)$ \\
\hline \multicolumn{7}{|c|}{ Subsidiary-level independent variables } \\
\hline SIZE & Log of subsidiary employees no & & & $0.22 * * *(0.01)$ & & $0.60 * * *(0.04)$ \\
\hline AGE & Log of subsidiary age & & & $0.29 * * *(0.07)$ & & $0.21 * *(0.09)$ \\
\hline \multicolumn{7}{|l|}{ Locational Interaction } \\
\hline PERVASIVE $X$ TRANSPERI & Pervasiveness X Transitional P & & & & $-0.09 * *(0.03)$ & $-0.06 * *(0.03)$ \\
\hline ARBITR X TRANSPERI & Arbitrariness $\mathrm{X}$ Transitional $\mathrm{P}$ & & & & $-0.08 * *(0.02)$ & $-0.05 *(0.03)$ \\
\hline \multicolumn{7}{|l|}{ Location (country cluster) } \\
\hline TRANSPERI & Transitional periphery location & $-0.33 * * *(0.06)$ & & & $-0.56 * * *(0.12)$ & $-0.51 * * *(0.11)$ \\
\hline \multicolumn{7}{|l|}{ Parent-level controls } \\
\hline DCMNE & DCMNE parent & $0.02(0.07)$ & $0.11(0.07)$ & $0.17 * *(0.05)$ & $0.09(0.07)$ & $0.03(0.06)$ \\
\hline EMNE & ECMNE parent & $-0.26 * *(0.10)$ & $-0.17(0.11)$ & $-0.20 * *(0.08)$ & $-0.12(0.11)$ & $-0.14 *(0.08)$ \\
\hline \multicolumn{7}{|l|}{ Industry-level controls } \\
\hline MANUFACT & Manufacturing & $0.16^{*}(0.10)$ & $0.27 * *(0.13)$ & $-0.05(0.08)$ & $0.14 *(0.12)$ & $-0.08(0.10)$ \\
\hline TRADE & Wholesale and retail & $-0.42 * * *(0.11)$ & $-0.29 * *(0.14)$ & $-0.33 * *(0.08)$ & $-0.38 * *(0.13)$ & $-0.32 * *(0.11)$ \\
\hline CONSTR & Construction & $-0.19(0.12)$ & $-0.12(0.14)$ & $-0.23 * *(0.09)$ & $-0.19(0.14)$ & $-0.21 *(0.11)$ \\
\hline HOSPTY & Hospitality & $0.18(0.15)$ & $0.17(0.17)$ & $-0.09(0.12)$ & $0.09(0.17)$ & $-0.08(0.14)$ \\
\hline \multicolumn{2}{|l|}{ Intercept } & $1.80 * * *(0.11)$ & $1.56 * * *(0.16)$ & $0.51 * * *(0.12)$ & $1.95 * * *(0.13)$ & $0.82 * *(0.20)$ \\
\hline \multicolumn{2}{|l|}{ F statistic } & $19.27 * * *$ & $9.31 * * *$ & $57.76^{* * *}$ & $13.30 * * *$ & $26.93 * * *$ \\
\hline \multicolumn{2}{|l|}{ Adjusted R-square } & 0.21 & 0.20 & 0.47 & 0.22 & 0.55 \\
\hline
\end{tabular}


Table 4: Results of Subgroup Regression Analysis for Size and Age of Operations (Dependent Variable: REINVEST)

\begin{tabular}{|c|c|c|c|c|}
\hline \multirow[b]{2}{*}{ Variables } & \multirow[b]{2}{*}{ Definition } & \multirow[b]{2}{*}{$\begin{array}{l}\text { Model } 1 \\
\text { Full } \\
\text { Sample }\end{array}$} & \multicolumn{2}{|c|}{ Country Cluster } \\
\hline & & & $\begin{array}{c}\text { Model 2a } \\
\text { Transitional } \\
\text { Periphery }\end{array}$ & \begin{tabular}{|c|} 
Model 2b \\
Post Soviet \\
Transitional EU \\
Members
\end{tabular} \\
\hline $\begin{array}{l}\text { Independent } \\
\text { variables: Subsidiary } \\
\text { level }\end{array}$ & & Model 1 & Model 2 & Model 3 \\
\hline SIZE & Log of subsidiary employees no & $0.227 * * *$ & $0.680 * * *$ & $0.605 * * *$ \\
\hline AGE & Log of subsidiary age & $0.298 * * *$ & 0.111 & $0.385 * * *$ \\
\hline \multicolumn{5}{|l|}{ Parent-level controls } \\
\hline DCMNE & DCMNE parent & $0.174 * *$ & $0.171^{* *}$ & 0.020 \\
\hline EMNE & ECMNE parent & $-0.208 * *$ & $-0.116^{* *}$ & 0.133 \\
\hline \multicolumn{5}{|l|}{$\begin{array}{l}\text { Industry-level } \\
\text { controls }\end{array}$} \\
\hline MANUFACT & Manufacturing & -0.050 & -0.142 & -0.029 \\
\hline TRADE & Wholesale and retail & $-0.333 * *$ & $-0.296 * *$ & $-0.303 * *$ \\
\hline CONSTR & Construction & $-0.232 * *$ & -0.231 & $-0.199 *$ \\
\hline \multirow[t]{2}{*}{ HOSPTY } & Hospitality & -0.091 & -0.124 & -0.030 \\
\hline & Intercept & $0.513 * * *$ & 0.262 & $0.319 * *$ \\
\hline$F$ value & & $57.76^{* * *}$ & $24.69 * * *$ & $38.49 * * *$ \\
\hline Adjusted $R^{2}$ & & 0.472 & 0.490 & 0.556 \\
\hline$F_{\text {ChowT }}$ value $^{\dagger}$ & & & \multicolumn{2}{|c|}{$5.436 * * *$} \\
\hline
\end{tabular}

\section{Notes:}

$* p<0.1 ; * * p<0.05 ; * * * p<0.01$

${ }^{\dagger} F$ value for Chow test can be defined as $F_{\text {Chow } T}=\left[\left(R S S E_{P}-\sum_{i=1}^{g} R S S E_{i}\right) /(g-1) k\right] / \sum_{i=1}^{g} R S S E_{i} /(n-g k)$, where RSSE stands for the residual sum of squared errors, $n$ is the full sample $p$ size, $k$ is the number of estimated coefficients, and $g$ is the number of subgroups. 
Fig. 1: A Summary and direction of hypotheses

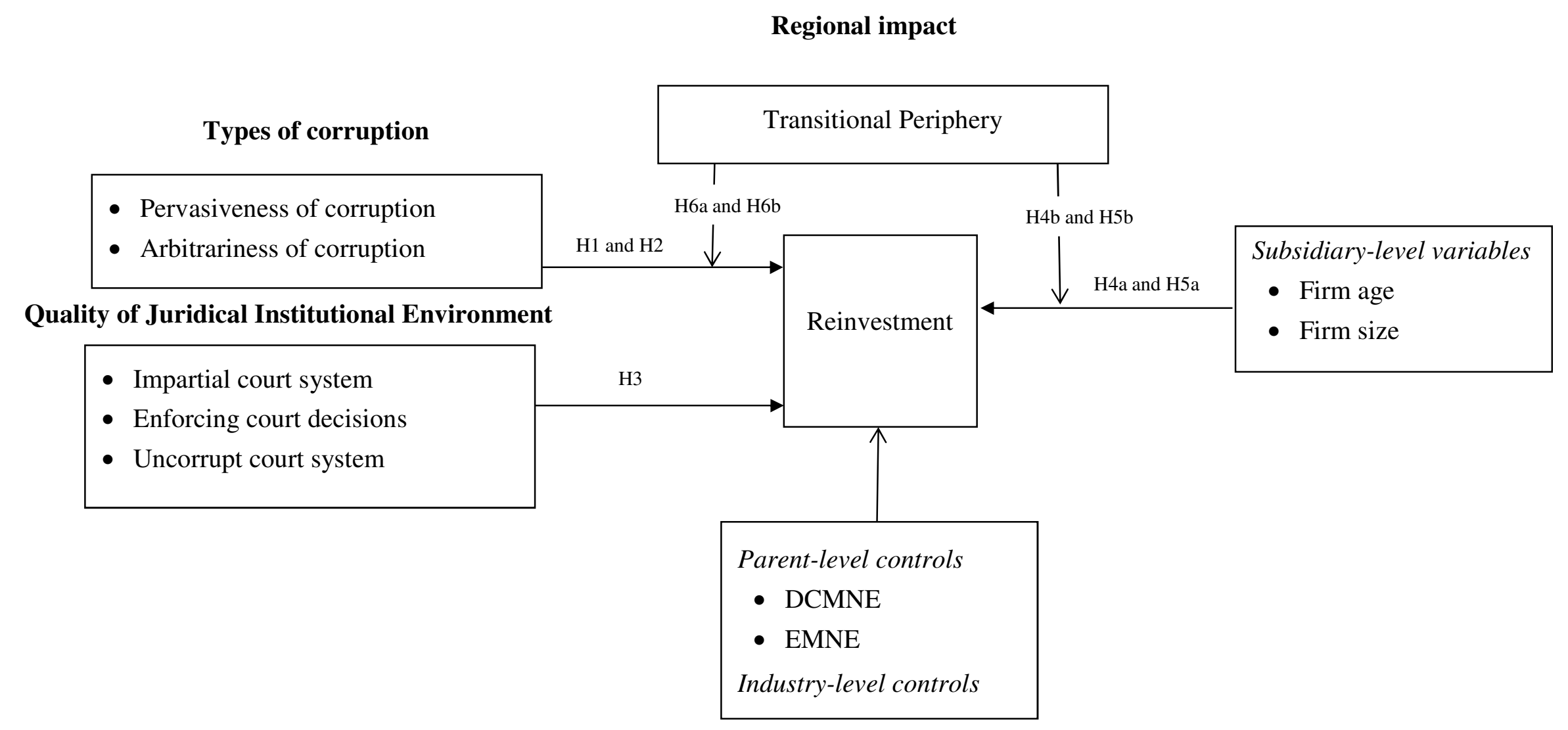

\section{Control Variables}




\section{REFERENCES}

Acemoglu, D., Johnson, S., \& Robinson, J. A. (2012). The Colonial Origins of Comparative Development: An Empirical Investigation: Reply. American Economic Review, 102, 3077-3110.

Acs, Z., Morck, R., Shaver, J., \& Yeung, B. (1997). The Internationalization of Small and Medium-Sized Enterprises: A Policy Perspective. Small Business Economics, 9, 7-20.

Aidt, T. S. (2009). Corruption, institutions, and economic development. Oxford Review of Economic Policy, 25, 271-291.

Aldrich, H. E., \& Auster, E. (1986). Even dwarfs started small: liabilities of age and size and their strategic implications. In B. M. Staw \& L. L. Cummings (Eds.), Research in Organizational Behavior (Vol. 8). Greenwich, CT: JAI Press.

Alqhuist, J. S., \& Prakash, A. (2010). FDI and the costs of contract enforcement in developing countries. Policy Sciences, 43, 181-200.

Auty, R. M. (2006). Patterns of Rent-Extraction and Deployment in Developing Countries: Implications for Governance, Economic Policy and Performance. In G. Mavrotas \& A. Shorrocks (Eds.), Advancing Development: Core Themes in Global Economics. London: Palgrave.

Aysan, A. F., Nabli, M. K., \& Veganzones-Varoudakis, M. A. (2007). Governance institutions and private investment: An application to the Middle East and North Africa. Developing Economies, 45, 339-377.

Ayyagari, M., Demirgüç-Kunt, A., \& Maksimovic, V. (2014). Bribe payments and innovation in developing countries: Are innovating firms disproportionately affected? Journal of Financial and Quantitative Analysis, 49, 51-75.

Baughn, C., Bodie, N. L., Buchanan, M. A., \& Bixby, M. B. (2010). Bribery in International Business Transactions. Journal of Business Ethics, 92, 15-32.

Baum, J.A.C., \& Shipilov, V. (2006). Ecological approaches to organizations. In S. R. Clegg, C. Hardy, T. Lawrence \& W. Nord (Eds.), Handbook of Organization Studies (pp. 55-110). Thousand Oaks, CA: Sage.

Beck, T., Demirguc-Kunt, A., \& Maksimovic, V. (2005). Financial and legal constraints to growth: Does, firm size matter? Journal of Finance, 60, 137-177.

Bercovitz, J., \& Mitchell, W. (2007). When is more better? The impact of business scale and scope on long-term business survival, while controlling for profitability. Strategic Management Journal, 28, 61-79.

Blackburn, K., \& Forgues-Puccio, G. F. (2009). Why is corruption less harmful in some countries than in others? Journal of Economic Behavior and Organization, 72, 797-810.

Bliss, C., \& Tella, R. D. (1997). Does Competition Kill Corruption? Journal of Political Economy, 105, 1001-1023.

Blomström, M., \& Kokko, A. (1998). Multinational Corporations and Spillovers. Journal of Economic Surveys, 12, 247-277.

Bondy, K., \& Starkey, K. (2014). The dilemmas of internationalization: Corporate social responsibility in the multinational corporation. British Journal of Management, $25,4-22$ 
Bradley, S. W., Aldrich, H., Shepherd, D. A., \& Wiklund, J. (2011). Resources, environmental change, and survival: asymmetric paths of young independent and subsidiary organizations. Strategic Management Journal, 32, 486-509.

Chakravarty, S., \& Xiang, M. (2011). Determinants of profit reinvestment by small businesses in emerging economies. Financial Management, 40, 553-590.

Chandler, D. (2006). State-building in Bosnia: The limits of 'informal trusteeship'. International Journal of Peace Studies, 11, 17-38.

Chung, C. C., \& Beamish, P. W. (2005). Investment mode strategy and expatriate strategy during times of economic crisis. Journal of International Management, 11, 331-355.

Collins, J. D., Uhlenbruck, K., \& Rodriguez, P. (2009). Why firms engage in corruption: A top management perspective. Journal of Business Ethics, 87, 89-108.

Collins, K. (2009). Economic and Security Regionalism among Patrimonial Authoritarian Regimes: The Case of Central Asia. Europe-Asia Studies, 61, 249-281.

Cuervo-Cazurra, A. (2006). Who Cares about Corruption? Journal of International Business Studies, 37, 807-822.

Cuervo-Cazurra, A. (2008). Better the devil you don't know: Types of corruption and FDI in transition economies. Journal of International Management

International business and institutional development in Central and Eastern Europe, 14, 12-27.

Cull, R., \& Xu, L. C. (2005). Institutions, ownership, and finance: the determinants of profit reinvestment among Chinese firms. Journal of Financial Economics, 77, 117-146.

Demirbag, M., McGuinness, M., \& Altay, H. (2010). Perceptions of Institutional Environment and Entry Mode: FDI from an Emerging Country. Management International Review, 50(2), 207-240.

Demirbag, M., Tatoglu, E., \& Apaydin, M. (2011) Survival of Japanese subsidiaries in the Middle Eat and Africa, Journal of World Business, 46(4):411-425.

Diaby, A., \& Sylwester, K. (2014). Bureaucratic competition and public corruption: Evidence from transition countries. European Journal of Political Economy, 35, 75-87.

DiMaggio, P. J., \& Powell, W. W. (1983). The iron cage revisited: institutional isomorphism and collective rationality in organizational fields. American Sociological Review, 48, 147-160.

Djankov, S., La Porta, R., Lopez-De-Silanes, F., \& Shleifer, A. (2003). Courts. Quarterly Journal of Economics, 118, 453-518.

Doh, J. P., Rodriguez, P., Uhlenbruck, K., Collins, J., \& Eden, L. (2003). Coping with corruption in foreign markets. Academy of Management Executive, 17, 114-127.

Dore, R. (2000). Stock Market Capitalism: Welfare Capitalism. Cambridge: Cambridge University Press.

Durnev, A., Errunza, V., \& Molchanov, A. (2010). Property rights protection, corporate transparency, and growth. Journal of International Business Studies, 40,15331562

Eden, L., Levitas, E., \& Martinez, R. J. (1997). The Production, Transfer and Spillover of Technology: Comparing Large and Small Multinationals as Technology Producers. Small Business Economics, 9, 53-66. 
Frye, T., \& Shleifer, A. (1997). The Invisible Hand and the Grabbing Hand. The American Economic Review, 87, 354-358 CR - Copyright \&\#169; 1997 American Economic Association.

Geroski, P. A., Mata, J., \& Portugal, P. (2010). Founding conditions and the survival of new firms. Strategic Management Journal, 31, 510-529.

Giddens, A. (1984). The Constitution of Society. Cambridge: Polity.

Ghosal, V., \& Loungani, P. (2000). The Differential Impact of Uncertainty on Investment in Small and Large Businesses. Review of Economics and Statistics, 82, 338-343.

Gomes, E., Sahadev, S., Glaister, A. J., \& Demirbag, M. (2014). A comparison of international HRM practices by Indian and European MNEs: evidence from Africa. The International Journal of Human Resource Management, 1-25. (ahead of print) doi: 10.1080/09585192.2014.939986

Gomes, E., Sahadev, S., Glaister, A. J., \& Demirbag, M. (2014). A comparison of international HRM practices by Indian and European MNEs: evidence from Africa. The International Journal of Human Resource Management, 1-25.

Gullette, D. (2010). The Genealogical Construction of the Kyrgyz Republic: Kinship, State and Tribalism. Folkstone, UK: Global Oriental Ltd.

Haggard, S., MacIntyre, A., \& Tiede, L. (2008). The rule of law and economic development. Annual Review of Political Science, 11, 205-234.

Hair, J. F., Black, W. C., Babin, B. J., Anderson, R. E., \& Tatham, R. L. (2006). Multivariate data analysis (6th ed.). Upper Saddle River, NJ: Pearson-Prentice Hall.

Hall, P. A., \& Soskice, D. (2001). Varieties of Capitalism: The Institutional Foundations of Comparative Advantage. Oxford: OUP.

Hallward-Driemeier, M. (2009). Who survives ? the impact of corruption, competition and property rights across firms. In Policy Research Working Paper no. 5084. Washington, D.C.: World Bank.

Henderson, A. D. (1999). Firm Strategy and Age Dependence: A Contingent View of the Liabilities of Newness, Adolescence, and Obsolescence. Administrative Science Quarterly, 44, 281-314.

Henisz, W. J. (2000). The institutional environment for multinational investment. Journal of Law, Economics and Organization, 16, 334-364.

Herbst, J. (2000). States and Power in Africa: Comparative Lessons in Authority and Control. Princeton, NJ: Princeton University Press.

Hines, J. R. (1995). Forbidden payment: foreign bribery and American business after 1977. In. Cambridge, Mass.: National Bureau of Economic Research.

Holmberg, S., Rothstein, B., \& Nasiritousi, N. (2009). Quality of Government: What You Get. Annual Review of Political Science, 12, 135-161.

Hoskisson, R. E., Eden, L., Lau, C. M., \& Wright, M. (2000). Strategy in emerging economies. Academy of Management Journal, 43, 249-258.

Huntington, S. P. (1968). Political order in Changing Societies. New Haven, CT: Yale University Press.

Johnson, S., McMillan, J., \& Woodruff, C. (2002). Property Rights and Finance. The American Economic Review, 92, 1335-1356.

Kaufmann, D., Kraay, A., \& Mastruzzi, M. (2007). Governance Matters VI: Governance Indicators for 1996-2006. World Bank Policy Research Working Paper No. 4280. 
Kaufmann, D., \& Wei, S.-J. (2000). Does 'grease money' speed up the wheels of commerce? In International Monetary Fund Policy Working Paper, WP/00/64.

La Porta, R., Lopez, F., \& Shleifer, A. (2008). The economic consequences of legal origins. Journal of EconomicLiterature, 4, 285-332.

La Porta, R., Lopez, F., Shleifer, A., \& Vishny, R. W. (1999). The quality of government. Journal of Law, Economics and Organization, 15, 222-279.

La Porta, R., Lopez, F., Shleifer, A., \& Vishny, R. W. (2002). Investor protection and corporate valuation. Journal of Finance, 3, 1147-1170.

Lane, C., \& Wood, G. T. (2012). Capitalist Diversity and Diversity within Capitalism. In. London: Routledge.

Lee, S.-H., Oh, K., \& Eden, L. (2010). Why do firms bribe? Management International Review, 50, 775-796.

Lee, S.-H., \& Oh, K. (2007). Corruption in Asia: Pervasiveness and arbitrariness. Asia Pacific Journal of Management, 24, 97-114.

Leff, N. (1964). Economic development through bureaucratic corruption. American Behavioral Scientist, 8, 8-14.

Li, J. (1995). Foreign entry and survival: Effects of strategic choices on performance in international markets. Strategic Management Journal, 16, 333-351.

Lskavyan, V., \& Spatareanu, M. (2008). Host country's governance and the size of foreign investors. Economics Letters, 100, 258-261.

Lu, J. W., \& Xu, D. (2006). Growth and Survival of International Joint Ventures: An External-Internal Legitimacy Perspective. Journal of Management, 32, 426-448.

Lundan, S. (2006). Reinvested earnings as a component of FDI: an analytical review of the determinants of reinvestment. Transnational Corporations, 15, 35-66.

Makhija, M. V., \& Stewart, A. C. (2002). The effect of national context on perceptions of risk: A comparison of planned versus free-market managers. Journal of International Business Studies, 33, 737-756.

Makhija, M. (2003). Comparing the resource-based and market-based views of the firm: empirical evidence from Czech privatization. Strategic Management Journal, 24, 433-451.

Mata, J., \& Portugal, P. (2002). The survival of new domestic and foreign-owned firms. Strategic Management Journal, 23, 323-343.

McCarthy, A. M., Schoorman, F. D., \& Cooper, A. C. (1993). Reinvestment decisions by entrepreneurs: Rational decision-making or escalation of commitment? Journal of Business Venturing, 8, 9-24.

Mauro, P. (1995). Corruption and Growth. Quarterly Journal of Economics, 110, 681712.

Mellahi, K., Demirbag, M. \& Wood, G. (2012). Regulatory context and corruption: Rethinking the effects of government intervention. International Studies of Management and Organization, 42(3), 13-34.

Meon, P. G., \& Sekkat, K. (2005). Does corruption grease or sand the wheels of growth? Public Choice, 122, 69-97.

Meschi, P. X. (2009). Government corruption and foreign stakes in international joint ventures in emerging economies. Asia Pacific Journal of Management, 26, 241261. 
Meyer, K. E. (2001). Institutions, transaction costs and entry mode choice in Eastern Europe. Journal of International Business Studies, 32, 357-367.

Meyer, K. E., \& Sinani, E. (2009). When and where does foreign direct investment generate positive spillovers? A meta-analysis. Journal of International Busines Studies, 40, 1075-1094.

Mitchell, W. (1994). The Dynamics of Evolving Markets: The Effects of Business Sales and Age on Dissolutions and Divestitures. Administrative Science Quarterly, 39, 575-602.

Mudambi, R. (1998). The Role of Duration in Multinational Investment Strategies. Journal of International Business Studies, 29, 239-261.

North, D. C. (1981). Structure and Change in Economic History. New York, N.Y.: W.W. Norton \& Co.

North, D. C. (1990). A Transaction Cost Theory of Politics. Journal of Theoretical Politics, 2, 355-367.

Nur-Tegin, K., \& Sahin, T. (2013). Bribing behaviour by firm attributes: An empirical analysis. International Journal of Public Policy, 9, 231-244.

Ozawa, T. (2009). The role of multinationals in sparking industrialization: From "infant industry protection" to "FDI-led industrial take-off". Columbia FDI Perspectives, 39

Peel, M. (2010). Prosecutors to push on with £30m BAE deal. In Financial Times. London.

Peel, M., \& Kirchgaessner, S. (2010). BAE to pay $\$ 450 \mathrm{~m}$ in corruption probe deal. In Financial Times. London.

Rodriguez, P., Uhlenbruck, K., \& Eden, L. (2005). Government corruption and the entry strategies of multinationals. Academy of Management Review, 30, 383-396.

Roy, J. P., \& Oliver, C. (2009). International joint venture partner selection: The role of the host-country legal environment. Journal of International Business Studies, 40, 779-801.

Sahadev, S., \& Demirbag, M. (2011). Exploring variations in employment practices in the emerging economies of Europe: assessing the impact of foreign ownership and European integration. Human Resource Management Journal, 21(4), 395-414.

Sarkar, M. B., Echambadi, R., Agarwal, R., \& Sen, B. (2006). The effect of the innovative environment on exit of entrepreneurial firms. Strategic Management Journal, 27, 519-539.

Shleifer, A., \& Vishny, R. W. (1993). Corruption. Quarterly Journal of Economics, 108, 599-617.

Shleifer, A., \& Vishny, R. W. (1998). The Grabbing Hand: Government Pathologies and Their Cures. Cambridge, Mass.:Harvard University Press.

Spencer, J., \& Gomez, C. (2010). MNEs and corruption: the impact of national institutions and subsidiary strategy. Strategic Management Journal, 32, 280-300.

Svensson, J. (2003). Who Must Pay Bribes and How Much? Evidence from A Cross Section of Firms. Quarterly Journal of Economics, 118, 207-230.

Thelen, K. (2010). Beyond comparative statics. In G. Morgan, J. Campbell, C. Crouch, O. Pedersen \& R. Whitley (Eds.), The Oxford handbook of comparative institutional analysis (pp.41-62). Oxford: Oxford University Press. 
Thornberry, J., Sidani, Y. M., \& Apaydin, M. (2014). Role of Informal Networks in Mitigating the Liability of Outsidership: Case of the Iranian Bazaar. Academy of Management Proceedings, 2014

Uhlenbruck, K., Rodriguez, P., Doh, J., \& Eden, L. (2006). The impact of corruption on entry strategy: Evidence from telecommunication projects in emerging economies. Organization Science, 17, 402-414.

United Nations. (2000). United Nations Millenium Declaration 55/2. In.

Wei, S.-J. (1997). Why is corruption so much more taxing than tax? Arbitrariness kills.

In. Cambridge, Mass.: National Bureau of Economic Research.

Wood, D. (2011). The Current Limits and Potential Role of Institutional Investment Culture and Fiduciary Responsibility.

Wood, G. T. (2011). Governance, Finance and Industrial Relations. In K. Townshend \&

A. Wilkinson (Eds.), Research Handbook on the Future of Work and Employment Relations (pp. 279-295). Cheltenham: Edward Elgar Publishing Ltd.

Wood, G. T., \& Lane, C. (2012). Institutions, Change and Diversity. In C. Lane \& G. Wood (Eds.), Capitalist Diversity and Diversity within Capitalism. London: Routledge.

World Bank. (2010). The World Bank Group Debars Macmillan Limited for Corruption in World Bank-supported Education Project in Southern Sudan. In (Vol. Press release). Washington D.C.: World Bank Group.

Wren, C., \& Jones, J. (2009). Re-investment and the survival of foreign-owned plants. Regional Science and Urban Economics, 39, 214-223.

Zaheer, S. (1995). Overcoming the liability of foreignness. Academy of Management Journal, 38, 341-363.

Zimmerman, M. A., \& Zeitz, G. J. (2002). Beyond Survival: Achieving New Venture Growth by Building Legitimacy. The Academy of Management Review, 27, 414431. 